\title{
Green Advertising and Environmentally Responsible Consumer Behavior: The Level of Awareness and Perception of Malaysian Youth
}

\author{
Mohd Helmi Abd Rahim \\ Universiti Kebangsaan Malaysia, Malaysia \\ E-mail: mhelmi@ukm.my \\ Ros Zayanah Johari Ahmad Zukni \\ Mydeal.com.my, Malaysia \\ E-mail: zayanah_zukni@yahoo.co.uk \\ Fauziah Ahmad \& Novel Lyndon \\ Universiti Kebangsaan Malaysia, Malaysia \\ E-mail: zuhair@ukm.my,novel@ukm.my
}

Received: February 28, 2012

Accepted: March 13, $2012 \quad$ Published: April 16, 2012

doi:10.5539/ass.v8n5p46

URL: http://dx.doi.org/10.5539/ass.v8n5p46

\begin{abstract}
The study determines to find the level of awareness and perception on green living amongst Malaysian youth through the use of advertising. The main objective is to explore awareness and perception of Malaysian youth towards green advertising promoted by the government. A survey was conducted to gather responses from online respondents using the social media website. Three hundred and twenty respondents have responded to the six month survey time, to a 20 questions questionnaire. The result indicates that, generally, the Malaysian youth have some awareness on what the term 'green living' denotes. However, those who practice green living are lower. They have been exposed to green advertising, but not all practice green living due to the lack of comprehensive understanding of the concept. The Malaysian youth exhibit positive perception towards green advertising. The finding concludes that there is a need for current and upcoming green advertising, especially ones that are done by the government to improve on their message delivery, creativity and information for the youth to respond in practice.
\end{abstract}

Keywords: Green advertising, Green living, Environmental awareness, Perception, Youth

\section{Introduction}

The green issue is a worldwide issue. Countries have been actively adopting the sustainable green living concept in mitigating the negative by-products of development and modernization, to name a few, pollution and deterioration of natural resources. The Obama administration in the U.S. was reported to have spent USD150 billion for their investment plan of clean energy, hybrid cars and renewable power (Desan, 2009). The Asian regions too, embracing the power of 'going-green' as environmental threats are disturbing local governments and citizens (Lee, 2008). The Malaysian Green Technology Policy is the nation's commitment to the vision of a 'Green Malaysia' a reality. The Green Technology Policy was launched on $24^{\text {th }}$ July 2009 by the Prime Minister of Malaysia. The said policy outlined five strategic areas in implementing the 'Green Malaysia' framework; (i) strengthening institutional frameworks, (ii) providing a conducive environment for green technology development, (iii) intensifying human capital development in green technology, (iv) intensifying green technology research and innovations, and (v) undertaking of promotions to increase public awareness (Desan, 2009). 
Much has been done to achieve these strategic thrusts. The property sector, for instance, has seen the rise in the development of green buildings such as the Gtower and 1First Avenue. Hypermarket chains such as Jusco and Carrefour have adopted the No Plastic Bag Day policy on Saturdays in their bid to reduce dependency on plastic. The corporate sector has joined in with campaigns such as Sime Darby's Plant a Tree Program and Digi's Mangrove-Saving Project. At hand, various parties have made efforts in promoting green concept and as to raise the public awareness. The government has been actively involved in green advertising promoting the green campaigns.

Green advertising can be seen as any advertisement that may explicitly or implicitly addresses the relationship between a product and the biophysical environment (Banerjee, Gulas \& Iyer, 1995). It should also have the characteristics of being able to promote a green lifestyle and, at times, enhance a corporate image of social responsibility. Government's green advertising campaign, besides promoting the green environment concept, embeds the promotion of good living and of government's good image to the citizen.

This research studies on the green advertising campaigns done by the government. Research has been somewhat limited in studies regarding green advertising (Mayor, Scammon \& Zick, 1992; Scammon \& Mayer, 1991), more so in countries where the level of awareness is still at its infancy. There is also little known about the nature of what green consumer perceive as important in green advertisement. There is also lack of research on government green advertising campaigns, as past researches were mostly conducted on the perception or attitude towards green products and corporate green claims (e.g. Cox, 2008; Haytko \& Matulich, 2008; D'Souza, Taghian, Lamb \& Peretiatko, 2007; D’Souza \& Taghian, 2005). This study, therefore, provides a much needed insight into local (Malaysia) and governmental green advertising campaigns. It hopes to contribute towards the effectiveness of future green campaigns. The primary goal of this study is to assess the level of awareness and perception of Malaysian youth towards green advertising campaigns by the government.

The study focuses on two distinctive areas, namely, the environmental knowledge and the level of involvement of Malaysian youth, and, how do the green advertisements, propagated by the government contribute or influence the factors mentioned. Two hypothetical statements are to be tested; (i) Youth who have the knowledge on 'green living' will respond positively to green advertising, and, (ii) Youth who are generally concerned for the environment are more aware of green advertising compared to those who do not.

The study aims to gauge the level of green living awareness, and to evaluate the effectiveness of advertising as a platform in delivering information on green living to Malaysian youth. The result of this study will later hope to contribute in terms of improving 'message delivery' and the effectiveness of advertising to the target group (youth).

\section{Concept Definition}

Green advertising are advertisements that promote products, services, ideas or organizations' ability to help or reduce environmental harm. Green living is an attempt to carry out life in an eco-friendly, environmentally responsible manner, and, an attempt to minimize the size of our ecological footprint. Environmental awareness is seen as the growth and development of awareness, understanding and consciousness toward the biophysical environment and its problems, including human interactions and effects. Environmental attitude is defined as a learned predisposition to respond consistently favorable or unfavorable manner with respect to the environment (Rashid, 2009).

According to Shrum, McCarty and Lowrey (1995), green research can be categorized into consumer based and advertising based. Consumer based identifies characteristics of consumer that differentiate between levels of environmental concern. Shrum, McCarty and Lowrey (1995) conclude that a green consumer is anyone whose purchase behavior is influenced by environmental concerns. While there has been a substantive number of researches on consumer characteristics (e.g. Banerjee, Gulas \& Iyer, 1995; Schlegelmilch, Diamantopoulous \& Bohlen, 1994), there is no consensus about the 'true' profile of a green consumer (D'Souza, Taghian, Lamb \& Peretaitko, 2007). This study focuses on the advertising based perspective, i.e. investigating on the level of green awareness, as well as the effectiveness of green advertising campaign in influencing consumer's perception and attitude.

Interest in green research began to substantiate since early 1990's but somewhat limited in studies regarding green advertising (e.g. Mayer, Scammon \& Zick, 1992; Scammon \& Mayer, 1991), and of recent, mostly conducted on the perception or attitude towards green products and corporate green claims (Cox, 2008; Haytko \& Matulich, 2008; D'Souza \& Taghian, 2005). A chronological report of green advertising research; study by Chase and Smith (1992) indicated that only 6\% consumer believed that environmental advertising were 'very believable', and $90 \%$ indicated that these advertising claims were 'somewhat', 'not very' or 'not at all 
believable'. The study was later supported by Kilbourne's (1995) finding that the level of credibility of green advertising is relatively low. After 10 years, D'Souza and Taghian (2005) found that there is a significant difference in the attitude of green advertising for high and low involvement consumer. Several studies emphasized the efficiency of cognitive persuasion strategies in green marketing, assuming the consumer's high involvement regarding environmental issues as a consequence of a growing environmental consciousness (Kinnear, Taylor \& Ahmed, 1974; Cope \& Winward, 1991; Hopfenbeck, 1993; Swenson \& Wells, 1997; Fuller, 1999).

The cognitive orientation of most green marketing research is based on studies showing a significant influence of environmental knowledge and consciousness on consumer's environmental attitude (Hines, Hungerford \& Tomera, 1987; Stone, Barnes \& Montgomery, 1995). However, several studies show only a limited influence of cognitive factors such as environmental knowledge, while demonstrating a significant influence of affective factors on environmental purchase behavior (Monhemius, 1993; Davis, 1993; Smith et. al. 1994; Finger, 1994). This factor also applies to emotional appeal effects in environmental advertising. A study by Ongkrutraksa (2003) found that emotional appeals can affect consumer's attitude towards environmental action, the degree of perceived consumer effectiveness (PCE) and consumer response towards environmental advertising. The study concludes that fear appeal in illustrations may be an effective tool in creating positive consumer attitude towards environmental action. The study provides an insight into the effectiveness of appeals in influencing consumer attitude.

Studies have also indicated that even if people have little knowledge about the environment, they would still exhibit strong emotional attachment to environment well-being (Ling-yee, 1997). A study by Haytko and Matulich (2008) to update previous researches on consumer's behavior and green advertising utilized a combination of several previously used measures with the addition of new items thought to tap the domains of attitude towards green advertising and environmental behaviors. Some of the new items are renewable energy (Rowlands, Parker \& Scott, 2002), eco-labeling (Brown \& Wahlers, 1998), climate change (Rowlands, Parker \& Scott, 2002) and eco-friendly cars (Buss, 2001). The study showed there was a significant difference between the environmentally responsible and environmentally apathetic groups on almost all green advertising questions. Those who were environmentally responsible exhibit more positive attitude towards green advertising compared to those who were environmentally apathetic. The study was also among the first study to specifically investigate gender differences to attitude towards green advertising and environmentally responsible behavior. Female consumer was found to exhibit more positive attitude towards green advertising and have increase amount of environmentalism.

Habib, Idrees and Khursheed (2010) studied on factors in environmental advertising that influence consumer's purchase intention and found that Pakistan consumer had adequate exposure to print and broadcast media, but television advertising is preferred. The study also shows that Pakistan's consumers are concern about their environment and intend to buy green products. Rashid (2009) studied the awareness of eco-labels in Malaysia's green marketing initiative, and found that a person having some concerned for the environment would have stronger preference for purchasing a green product, if he/she is made aware of its environmental friendly features through the use of eco-label. Nevertheless, environmental research has grown into many different perspectives and areas, over the years.

\section{Method}

This study employed the quantitative survey method. The questionnaire was distributed online via the social media website, the Facebook. This online platform was particularly chosen as it is less intrusive and it allows a wider coverage on respondents. Respondents were identified and selected through their Facebook profiles, of those who are qualified to be the sample (meaning the youth), and the stratified random sampling method was done. Youth are chosen as they can be regarded as the future generation of the country and are part of a growing group of consumer. Furthermore, it is assumed that younger individuals are more likely to be more sensitive to environment issues. Youth are identified as individuals between the ages of 18 to 28 .

The study was done in a period of 6 months. Three hundred and twenty responded within the time frame, picked according to the criteria wanted. Participation of respondents is purely voluntary. The questionnaire is divided into four sections. The first section consists of the demographic profile of respondents. The second section measures their media preferences and effectiveness where the Likert scale is used as the method of data collection. The third section measures a series of statements on green living employing the Likert measurement. Finally, the fourth section requires respondents to evaluate three green print advertisements placed by the government in various print media. The respondents are assumed, have somewhat being exposed to these 
advertisements before via the various media and, assumed to aid as a recall or reminder for the respondents. The semantic differential scale of 1 to 5 is used with 1 being the least effective and 5 being the most effective. The descriptive statistics is used in analyzing the data.

\section{Finding}

\subsection{Respondent background}

The three demographic factors are age, gender and educational level as stated in Table 1:

$<$ Insert Table 1 Here $>$

The highest of respondents are aged 20 to 22 or $62.5 \%$. This age group is among the highest Malaysian youth population, thus representing the general distribution of Malaysian youth population. Female tends to be $71 \%$ of the respondents, compare to male of only $29 \%$. The highest respondents in terms of education level are the undergraduates of $84 \%$, graduate $10 \%$ and high school $6 \%$. The education level is influenced by the age group distribution where age 20 to 22 , mostly undergraduates. The respondent background represents a fairly good distribution in contrast to the Malaysian youth population.

\subsection{Understanding the 'green living' concept}

The respondents are asked about their levels of understanding and practice of green living and exposure to green advertising. Table 2 shows $70 \%$ of respondents rate 'somewhat understand' in relation to their perception on the meaning of the term green living. This shows that the majority of respondents perceived themselves as more or less have an understanding of the green living concept. Meanwhile, those who perceived that they 'strongly understand' the term, are at $22 \%$ level. In contrast, only $7 \%$ perceived neutral to the term, while $1 \%$ admitted that they do not understand at all. Refer to Table 2:

$<$ Insert Table 2 Here>

In matter of practices 'green living', a large segment of the respondents (56\%) say that they 'somewhat agree' that they have been practicing 'green living' in their everyday life. Table 2 also shows that $12 \%$ of the respondents confirmed of practicing 'green living'. However, $26 \%$ of the respondents remain neutral and $6 \%$ admitted that they do not practice at all. The results in Table 2 shows that a large segment of the respondents have claimed that they 'somewhat understand' 'green living' (70\%) and 56\% of the respondents claimed they 'somewhat' practiced 'green living'. Interestingly, the understanding and the practice of green living shows a rather significant difference (14\%) as to compare the two measurement statements, with the mean score 3.21 and 2.94 respectively. This finding explains, as for the practice of 'green living' part, $26 \%$ of the respondents remain neutral as to compare to the understanding which stays at $7 \%$, making a significant difference of $19 \%$. This result indicates that understanding of 'green living' is not necessary to practice as equivalent or to the higher level.

Referring to respondents' exposure to green advertising the result indicates that $89 \%$ (285) have been exposed to green advertising before. The remaining $11 \%$ (35) respondents said that they have not been exposed. The 285 respondents were asked to list the green campaigns that they have heard/exposed of and the following result was obtained (Table 3):

\section{$<$ Insert Table 3 Here>}

The result (Table 3) shows that the Earth Hour campaign receives the most recognition at $99.1 \%$ of the respondents, the No Plastic Bag Day campaign at $92.7 \%$ and the $3 R$ at $86.2 \%$. Only $10.1 \%$ responds to have heard the 1 Malaysia Green \& Clean campaign. However, 5.5\% claimed that they have been exposed to other campaigns, mentioning the climate change, e-filing system in offices to reduce the usage of papers, earth day, reduce meat intake, community clean-up activities and 2 hours without motor vehicles campaigns.

\subsection{Media Usage}

The respondents were asked to rank four most effective media in delivering green messages for them. They were given four categories of media types. The result shows that the broadcast media is most preferred, the online media goes second, following the print media and lastly, the road shows and the exhibitions.

Nine options of specific media types were given to the respondents to rank in terms of media preference in receiving green messages. The results are as follows (Table 4):

$<$ Insert Table 4 Here $>$

The respondents perceived television as the most preferred medium in receiving green messages. This preference indicates that respondents are more prone to medium that provides sight and sound. The television actually the 
one medium that gives a clear understanding of seeing and hearing that comes together with television. They also prefer an interactive media, whereby the social networking websites ranked 2, and the websites ranked 3 . Radio, newspapers and magazines are convenient media for the youth and are ranked 4, 5 and 6 respectively. Being the least preferred, are road shows/exhibitions (7), blogs (8) and brochures (9).

\subsection{Awareness and perception}

The following results indicate the awareness and perception of the respondents to issues related with green messages, the 'green living' and environment. Refer to Table 5:

$<$ Insert Table 5 Here $>$

Malaysian youth shows positive concern about the environment $(77.6 \%, \mathrm{M}=3.88)$, and would willingly adopt a green lifestyle when exposed to persuasive green messages $(69.8 \%, M=3.49)$, although much lower to their positive concern about the environment. This results are coherent with the perception that the level of green awareness in Malaysia is still low $(72.8 \%, M=3.64)$. Nevertheless, only $67 \%(\mathrm{M}=3.35)$ perceived that the government and NGOs are doing a good job in promoting the 'green living' concept in Malaysia. They tend to be very positive that green advertising/campaigns are effective in educating and encouraging the youth to go green $(81 \%, M=4.05)$. They perceived that green advertising leads them to be more socially responsible $(75.8 \%$, $\mathrm{M}=3.79)$, and it is interesting to see $(71.6 \%, \mathrm{M}=3.58)$. However, they believed the green advertising/campaigns conducted/sponsored by the government are less interesting and less effective as compared to other findings $(58 \%, \mathrm{M}=2.90)$.

\subsection{Advertising Effectiveness}

The respondents were asked to gauge their perception on past three print green advertisements done by the government. They were given three images of these green advertisements and were asked to evaluate according to the message delivery efforts, design attractiveness/creativity and the effectiveness in prompting people to take action. A scale of 1 to 5 was given with three advertisements with titles, No Plastic Bag Day, 60 Earth Hour and $3 R$-Reduce, Reuse, Recycle, respectively. Refer to Table 6:

$<$ Insert Table 6 Here $>$

In terms of effectiveness of government sponsored green advertisements, respondents' overall evaluation on the three advertisements proved to be somewhat moderate (mean score from 2.75 to 3.38) across all areas of message delivery, design attractiveness/creativity and effectiveness in prompting people to take action.

\section{Discussion}

The study exhibits youth having strong attachment to the environment's well being despite having less knowledge about the environment (similar finding to Ling-yee, 1997). It was also found that youth who in general have some concern for the environment are more aware of green advertising. Malaysian youth, generally have some understanding on what the term 'green living' denotes. However, those who actually practice 'green living' are much lower comparatively. However, they show positive attitude to green advertising/campaigns. Thus, it can be concluded that those who have some knowledge on 'green living' exhibit positive attitude towards green advertising advertising/campaigns.

Nevertheless, the effectiveness of the advertisements/campaigns comprising of message delivery, design attractiveness/creativity and effectiveness in prompting people to take action are necessarily to be considered. Perhaps, it answers to the question why the actual practice of 'green living' is much lower. The youth needs more information of the "how" to do it rather than the "what" it is all about. The study proves this when the preferred media for green advertising/campaigns' of the top three to be television, social networking websites and the websites. These media vehicles are known to be giving more comprehensive information, like television for instance, provides the actual and moving visuals to be comprehended. The social networking websites are more popular to the youth, where it gives a platform for discussion among their peer groups. Whereas the websites may provides vast information, besides its interactive function. The government sponsored green advertising/campaigns must consider these media vehicles.

Green advertising/campaigns are perceived to be an effective tool to educate and to encourage the youth to go green and saw that the level of green awareness in Malaysia is still low. The awareness is high but the quality of the advertising/campaigns adhered by the government is perceived upon, as less effective and less interesting, not up to the standard. At least three areas should be improved to the green advertisements/campaigns, namely, the message delivery, design attractiveness/creativity and effectiveness of the message in prompting people to 
take action. The three advertisements used as measurement, in terms of effectiveness level, were considered moderate.

The 60 Earth Hour ad can be taken as an example of improving, at least on the three major areas. In terms of message delivery, this ad blends a good headline with its overall layout, and the meanings are easily derived by the consumer themselves, even with its limited copy. It seems that using Malaysian celebrities (Maya Karin and the late Yasmin Ahmad) proved to be somewhat effective in the design/creativity of the advertisement. The advertisement exudes a comical/humor element where Yasmin Ahmad is seen smiling happily as she points to the light switch, and Maya Karin stands stoically. In terms of taking action, the visual rather than word is enough for the consumer. Yasmin's action of pointing towards the light switch complements the advertisement's headline: Unite. Turn of the light. The other two advertisements, in contrast, relied more on copy writing to drive their messages, and are deemed to be less effective.

The success of green advertising/campaigns among the youth population in Malaysia has yet to be ascertained as to the level of public awareness. While youth generally has an idea of what the 'green living' concept is, and are aware of popular green advertising/campaigns, most of them do not have a thorough understanding of the matter. It somewhat proves why the lower level of practices of youth are to be found.

Youth perceived that generally green advertising/campaigns are an effective tool to educate and encourage positive behavioral change amongst them. However, there is a need for current and upcoming green advertising/campaigns, especially ones that are sponsored by the government to improve on their message delivery, creativity and selling power, if they want the consumer to be pro-active in responding to the messages.

The study has found that the use of print media is less effective as compared to television and online channels. The view was that, the former platform was less interesting as compared to the later, pertaining to youth and green advertising/campaigns. So do other forms of media as found in the study.

\section{Conclusion}

As a conclusion, the study has proven that advertising/campaigns can indeed be used as a vehicle to empower youth to embrace the green concept. It is undeniable that the government has taken the initiative to change the current situation of Malaysia into that of a better and 'greener' one. While efforts by the government are commendable, there is a need for better crafting of green messages and better execution of green advertising/campaigns.

\section{References}

Banerjee S., Gulas S. \& Iyer E. (1995). Shades of green: a multidimensional analysis of environmental advertising. Journal of Advertising, 23 Summer, 21-31.

Banerjee S. (2002). Organizational strategies for sustainable development: developing a research agenda for the new millennium. Australian Journal of Management, 27, 105-119. http://dx.doi.org/10.1177/031289620202701S11

Brown J.D. \& Wahlers R.G. (1998). The environmentally concerned consumer: an explanatory study. Journal of Marketing Theory and Practice, 6 (2), $39-48$.

Buss D. (2001). Green cars. American Demographics, 23 (1), 56-62.

Chase D. \& Smith T. (1992). Consumer's keen on green but marketers don't deliver. Advertising Age, Vol. 63 (June, 29), 2-4.

Cope D. \& Winward J. (1991). Information failures in green consumerism. Consumer Policy Review, 1, 2, 83-86.

Cox M. J. (2008). Sustainable communication: a study of green advertising and audience reception within the growing arena of corporate social responsibility: case study: British petroleum, earth and environment, 3, 32-51. Retrieved March 15, 2011, from: http://homepages.see.leeds.ac.uk/ lecac/ejournal/3,32 -51.pdf

Davis J.J. (1993). Strategies for environmental advertising. Journal of Consumer Marketing, 10, 2, 19-36. http://dx.doi.org/10.1108/07363769310039102

Desan J.N. (2009). The green market - opportunities, competencies, complexities. CSR Asia, 5, 40. Retrieved March 19, 2011, from: http://www.standardusers.org

D'Souza C. \& Taghian M. (2005). Green advertising effects on attitude and choice of advertising themes. Asia Pacific Journal of Marketing and Logistics, 17, 3, 9-21. 
D’Souza C., Taghian M., Lamb P. \& Peretiatko R. (2007). Green decisions: demographics and consumer understanding of environmental labels. International Journal of Consumer Studies, 31 (4), 371-376. http://dx.doi.org/10.1111/j.1470-6431.2006.00567.x

Environmental awareness definition. Retrieved April 17, 2011, from: http://www.eionet.europa.eu/gemet/concept?cp=2778

Finger M. (1994). From knowledge to action? Exploring the relationships between environmental experiences, learning and behavior. Journal of Social Issues, 50, 179-197. http://dx.doi.org/10.1111/j.1540-4560.1994.tb02424.x

Fuller D.A. (1999). Sustainable marketing. Thousand Oaks: Sage Publications.

Green advertising definition. Retrieved April 11, 2011, from: http://businesstraining.com/resources/what-is-green-advertising-definition-and-overview/

Habib A., Idrees A. \& Khursheed A. (2010). Factors in environmental advertising in influencing consumer's purchase intention. European Journal of Scientific Research, 48(2), 217-226, Retrieved April 2, 2011, from: http://www.eurojournals.com/ejsr.htm

Haytko D.L. \& Matulich E. (2008). Green advertising and environmentally responsible consumer behaviors: linkages examined. Journal of Management and Marketing Research, 1, 2-11.

Hines J.M., Hungerford H.R. \& Tomera A.N. (1987). Analysis and synthesis of research on responsible environmental behavior: a meta-analysis. Journal of Environmental Education, 18, 1-8. http://dx.doi.org/10.1080/00958964.1987.9943482

Hopfenback W. (1993). Direccio ‘n maketing ecolo’gicos. Madrid: Ediciones Deusto.

Kilbourne W. (1995). Green advertising: salvation or oxymoron? Journal of Advertising, 24(2), 7-19.

Kinnear T.C., Taylor J.R. \& Ahmed S.A. (1974). Ecological concerned consumers: who are they? Journal of the Academy of Marketing Science, 26(2), 143-152.

Lee K. (2008). Opportunities for green marketing: young consumers. Marketing Intelligence \& Planning, 26, 573-586. http://dx.doi.org/10.1108/02634500810902839

Ling-yee, L. (1997). Effect of collectivist orientation and ecological attitude on actual environmental commitment: the moderating role of consumer demographic and product involvement. Journal of International Consumer Marketing, 9(4), 31-54. http://dx.doi.org/10.1300/J046v09n04_03

Mayer R., Scammon D. \& Zick C. (1992). Turning the competition green: the regulation of environmental claims. In Paul N. Bloom and Richard G. Starr, Jr. (Eds.), Proceedings of the 1992 Marketing and Public Policy Conference. Chicago: American Marketing Association, 152-165.

Monhemius K.C. (1993). Umweltbewusstes kaufverhalten von konsumenten. Frankfurt am main: Peter Lang.

Ongkrutraksa W. (2003). Environmental communication in the digital age: a study of emotional appeal effects, Retrieved March 15, 2011 from: http://www.bu.ac.th/knowledgecenter/epaper/jan_june2005/worawan.pdf

Rashid N. A. (2009). Awareness of eco-label in Malaysia's green marketing initiative. International Journal of Business and Management, 4(8), 132-141.

Rowlands I. H., Parker P. \& Scott D. (2002). Consumer perceptions of green power. The Journal of Consumer Marketing, 19 (2/3), 112-130. http://dx.doi.org/10.1108/07363760210420540

Scammon D. \& Mayer R. (1991). Environmental labeling and advertising claims: international action and policy issues. Association for Consumer Research (Summer) Conference, Amsterdam, June, 338-348.

Schlegelmilch B.B., Diamantopoulos A. \& Bohlen G.M. (1994). The value of socio-demographic characteristics for predicting environmental consciousness. In Park C.W. and Smith D.C. (Eds.), Marketing Theory and Applications: The Proceedings of the 1994 American Marketing Association's Winter Educator's Conference, 5 , 341-352.

Shrum L., McCarty J. \& Lowrey T. (1995). Buyer characteristics of the green consumer and their implications for advertising strategy. Journal of Advertising, 24, 2, 71-82.

Stone G.B., Barnes J.H. \& Montgomery C. (1995). Ecoscale: a scale for the measurement of environmentally responsible consumers. Psychology and Marketing, 12(7), 595-612. http://dx.doi.org/10.1002/mar.4220120704 
Swenson M.R. \& Wells W.D. (1997). Useful correlates of pro-environmental behavior. In Goldberg M.E., Fishbein M. \& Middlestadt S.E. (Eds.), Social Marketing, Theoretical and Practical Perspectives. Mahwah: Lawrence Erlbaum, 91-109.

Table 1. Respondent Background

\begin{tabular}{|c|c|c|}
\hline Age & $f$ & $\%$ \\
\hline $18-20$ & 44 & 13.7 \\
\hline $20-22$ & 200 & 62.5 \\
\hline $23-25$ & 50 & 15.6 \\
\hline $26-28$ & 26 & 8.3 \\
\hline \multicolumn{3}{|l|}{ Gender } \\
\hline Female & 227 & 71.0 \\
\hline Male & 93 & 29.0 \\
\hline \multicolumn{3}{|c|}{ Education Level } \\
\hline High School & 19 & 6.0 \\
\hline Undergraduate & 269 & 84.0 \\
\hline Graduate & 32 & 10.0 \\
\hline
\end{tabular}

Table 2. The Concept of Green Living

\begin{tabular}{|c|c|c|c|c|c|c|c|c|c|}
\hline & & $\begin{array}{l}\text { ly Agree } \\
\%\end{array}$ & $\begin{array}{l}\text { Som } \\
\text { Agre } \\
f\end{array}$ & & & & $\begin{array}{l}\text { Do } \\
\text { Ag } \\
f\end{array}$ & Not & $\begin{array}{c}\text { Mean } \\
\quad M\end{array}$ \\
\hline Score & & 4 & & 3 & & 2 & & 1 & \\
\hline Understand 'Green Living' & 70 & 22.0 & 224 & 70.0 & 22 & 7.0 & 3 & 1.0 & 3.21 \\
\hline Practices 'Green Living' & 39 & 12.0 & 179 & 56.0 & 83 & 26.0 & 19 & 6.0 & 2.94 \\
\hline
\end{tabular}

Table 3. The Green Campaign/Advertising Exposed

\begin{tabular}{|l|lc|}
\hline Green Campaign & \multicolumn{2}{|c|}{ Number of respondents } \\
& \multicolumn{1}{|c|}{$f$} & $\%$ \\
\hline Earth Hour & 282 & 99.1 \\
\hline No Plastic Day & 264 & 92.7 \\
\hline 3R - Reduce, Reuse, Recycle & 246 & 86.2 \\
\hline 1 Malaysia Green \& Clean & 29 & 10.1 \\
\hline Others & 16 & 5.5 \\
\hline
\end{tabular}

Table 4. Media Preference

\begin{tabular}{|l|l|}
\hline Rank & \multicolumn{1}{|c|}{ Media Type } \\
\hline 1 & Television \\
\hline 2 & Social networking websites \\
\hline 3 & Websites \\
\hline 4 & Radio \\
\hline 5 & Newspapers \\
\hline 6 & Magazines \\
\hline 7 & Road shows/Exhibitions \\
\hline 8 & Blogs \\
\hline 9 & Brochures \\
\hline
\end{tabular}


Table 5. Awareness and Perception

\begin{tabular}{|c|c|c|c|c|c|c|c|c|c|c|c|}
\hline Statement & $\begin{array}{l}\mathrm{Str} \\
\mathrm{Ag}\end{array}$ & & Agr & & $\begin{array}{l}\text { Som } \\
\text { Agr }\end{array}$ & & Dis & & $\begin{array}{l}\text { Str } \\
\text { Dis }\end{array}$ & & Mean \\
\hline Score & & & & & & & & & & & \\
\hline & & $\%$ & & $\%$ & $f$ & $\%$ & & $\%$ & $f$ & $\%$ & $M$ \\
\hline $\begin{array}{l}\text { I am concern about the } \\
\text { environment }\end{array}$ & 26 & 8 & 205 & 64 & 83 & 26 & 6 & 2 & 0 & 0 & 3.88 \\
\hline $\begin{array}{l}\text { The level of green awareness in } \\
\text { Malaysia is still low }\end{array}$ & 22 & 7 & 148 & 46 & 144 & 45 & 6 & 2 & 0 & 0 & 3.64 \\
\hline $\begin{array}{l}\text { The Government and NGOs are } \\
\text { doing a good job in promoting the } \\
\text { 'green living' concept in Malaysia }\end{array}$ & 29 & 9 & 58 & 18 & 140 & 44 & 67 & 21 & 26 & 8 & 3.35 \\
\hline $\begin{array}{l}\text { Green advertising/campaigns are } \\
\text { effective in educating and } \\
\text { encouraging the youth to go green }\end{array}$ & 45 & 14 & 224 & 70 & 51 & 16 & 0 & 0 & 0 & 0 & 4.05 \\
\hline $\begin{array}{l}\text { Green advertising/campaigns } \\
\text { conducted by the Government are } \\
\text { interesting and effective }\end{array}$ & 0 & 0 & 16 & 5 & 231 & 72 & 45 & 14 & 28 & 9 & 2.90 \\
\hline $\begin{array}{l}\text { I will adopt a green lifestyle when } \\
\text { exposed to persuasive green } \\
\text { messages }\end{array}$ & 10 & 3 & 128 & 40 & 137 & 43 & 32 & 10 & 13 & 4 & 3.49 \\
\hline $\begin{array}{l}\text { Green advertising leads people to } \\
\text { be more socially responsible }\end{array}$ & 16 & 5 & 202 & 63 & 89 & 28 & 10 & 3 & 3 & 1 & 3.79 \\
\hline $\begin{array}{l}\text { Green advertising/campaigns are } \\
\text { interesting to see }\end{array}$ & 10 & 3 & 140 & 44 & 160 & 50 & 10 & 3 & 0 & 0 & 3.58 \\
\hline
\end{tabular}

Table 6. Advertising Effectiveness

\begin{tabular}{|c|c|c|c|}
\hline Areas & $\begin{array}{c}\text { No Plastic Bag Day } \\
\text { M }\end{array}$ & $\begin{array}{c}60 \text { Earth Hour } \\
\mathrm{M}\end{array}$ & $\begin{array}{l}3 \mathrm{R} \\
\mathrm{M}\end{array}$ \\
\hline Message delivery & 3.37 & 3.38 & 3.18 \\
\hline Design attractiveness/creativity & 2.84 & 3.35 & 2.75 \\
\hline Effectiveness in prompting people to take action & 2.91 & 3.15 & 2.76 \\
\hline
\end{tabular}

